\title{
WACANA KOMUNIKASI PESANTREN DI ERA REVOLUSI INDUSTRI 4.0
}

\author{
KUN WAZIS \\ IAIN Jember \\ kunwazis@gmail.com
}

Diunggah 11 Maret / Direvisi 01 April / Diterima 15 Juni 2020

\begin{abstract}
Abstrac: The Development of communication science in increasingly dynamic. The phenomena of health communication studies, tourism communication, corruption communication, for example, strengthen the position of communication science. The study tried to explain pesantren communication as a new study in communication studies.

This paper examined through a qualitatif descriptive approach with a literature study that focussed on two important aspect, namely communication and Islamic boarding school (pondok pesantren). The study of communication has a dimension to analysis reality based on messages or symbols displayed in human interaction, like on Islamic boarding school community. Beside that, Islamic boarding schools community showed many messages to interpreted by communition study.

The result of this study indicated that communication has the ability to interpreted many symbols or message on Islamic boarding community. And, Islamic boarding school as social change institution displays symbol or message that must be studied by communication studies. Pesantren communication can be categorized into a new variant in communication studies.
\end{abstract}

Keywords: Discourse, Islamic boarding school, Communication studies

Korespondensi: Kun Wazis

IAIN Jember

kunwazis@gmail.com 


\section{A. PENDAHULUAN}

Keberadaan pondok pesantren ${ }^{1}$ sebagai institusi pendidikan Islam khas Indonesia pada perkembangannya terus menarik dikaji dari berbagai perspektif keilmuan. Hal ini tidak lepas dari fungsi pondok pesantren ${ }^{2}$ yang dapat menyentuh dimensi kehidupan umat manusia sehingga melahirkan berbagai perubahan sosial di tengah-tengah masyarakat. Empat fungsi inilah yang menurut peneliti, pondok pesantren memiliki kemampuan menjawab berbagai tantangan zaman dengan kompleksitasnya.

Salah satu fenomena yang dihadapi negara Indonesia dalam tantangan era revolusi industri $4.0^{3}$ yang menuntut pelibatan semua pihak dalam menyikapi era serta digital tersebut. Sebagai suatu era yang merupakan konsep penggabungan teknologi digital dan internet dengan industri konvensional yang pada akhirnya bertujuan meningkatkan produktifitas, efisiensi dan layanan konsumen secara signifikan ${ }^{4}$ menjadikan semua pihak terkena dampak perkembangan teknologi informasi dan komunikasi ini. Untuk menghadapinya, pemerintah Indonesia melibatkan kalangan pondok pesantren dalam pemberdayaan ekonomi umat sebagai sumber daya manusia (SDM) yang mumpuni dalam menghadapi era berbasis internet ini. Seperti yang dilakukan Wakil Ketua Umum (Waketum) Kamar Dagang dan Industri Indonesia (Kadin) Arsjad Rasjid yang bekerja sama dengan Pondok Buntet Pesantren. Menurut Arsjad, harus ada sinergitas antara ponpes dengan para pengusaha untuk membangun ekonomi umat. Pihaknya melihat peran pesantren untuk membangun entrepreneur di masa-masa mendatang. Tidak hanya

\footnotetext{
${ }^{1}$ Dhofier (2011) memberikan batasan yang jelas mengenai sebuah institusi yang layak disebut pondok pesantren. Menurutnya, pondok, masjid, santri, pengajaran kitab Islam klasik dan kyai adalah lima elemen dasar tradisi pesantren. Ini berarti bahwa suatu lembaga pengajian yang telah berkembang hingga memiliki kelima elemen tersebut berubah statusnya menjadi pesantren. Lihat Zamakhsyari Dhofier, Tradisi Pesantren, Studi tentang Pandangan Hidup Kiai (Jakarta: LP3ES, 2011), 79-93

2 Eksan menyebut ada empat fungsi pondok pesantren, yakni sebagai lembaga pendidikan, lembaga dakwah, lembaga pengkaderan ulama, dan lembaga pengembangan masyarakat. Lihat Moch. Eksan, Dari Bom Bali Sampai Kuningan (Jember: LPM Filantropy Studies dan Pena Salsabila, 2009), 76-80.

3 Revolusi Industri 4.0 menerapkan konsep automatisasi yang dilakukan oleh mesin tanpa memerlukan tenaga manusia dalam pengaplikasiannya. Lihat http://binus.ac.id/knowledge/2019/05/mengenallebih-jauh-revolusi-industri-4-0/

4 Ainur Rofiq, Urgensi Dakwah Pemberdayaan Masyarakat di Era Industry 4.0 (Jurnal IJIC Pascasarjana IAIN Jember, Vol. 3, No. 1, Juni 2020), 18. Diakses melalui http://jurnalpasca.iainjember.ac.id/ejournal/index.php/IJIC/article/view/620/104
} 
memosisikan pesantren sebagai institusi untuk belajar agama, tetapi lebih pada pemberdayaan masyarakat ${ }^{5}$.

Problematika yang ditimbulkan oleh Revolusi Industri 4.0 direspon cepat oleh pondok pesantren di Indonesia yang jumlahnya mencapai 28.149 institusi. Sebagaimana dinyatakan Ketua Pengurus Besar Nahdlatul Ulama (PBNU), Sulton Fathoni, bahwa Industri 4.0 saat ini pesantren telah berorientasi pada pengembangan material yang sudah ada. Yakni, digitalisasi material pesantren yang lebih berorientasi 'enchancement' atas material yang sudah ada. Sulton mencontohkan digitalisasi yang dilakukan di pesantren, seperti alat pembelajaran sudah di aplikasikan dengan baik. Bahkan, pembelian barang-barang secara digital sudah terjadi dikalangan santri ${ }^{6}$.

Respon komunitas pesantren tidak berhenti pada perkembangan industri 4.0, tetapi sudah melangkah kepada Industri 5.0. Menurut Wakil Sekjen PBNU dan Pimpinan NU Channel, Imam Pituduh, mengatakan NU dan pesentran tidak lagi berkonsentrasi pada Revolusi Industri 4.0, tetapi telah dikonsentrasikan pada Industri 5.0. Hal ini disebabkan Industri 4,0 itu hanya tergantung pada perubahan informasi dan bidang IT yang menjadikannya tools bagi pesantren. Proses digitalisasi yang biasa digunakan seperti IOT (internet of things), cloud computing system sudah banyak digunakan di pesantren. Pesantren telah merambah beberapa bidang digital lainnya seperti, start-up, fintech dan tele education ${ }^{7}$.

Kemampuan pondok pesantren dalam merespon dinamika perkembangan zaman yang begitu cepat menjadikan posisi obyek pesantren sebagai realitas yang menarik untuk dikaji secara ilmiah. Pertama, pondok pesantren sebagai institusi yang mengkomunikasikan pesan-pesan ajaran Islam memiliki pengaruh yang besar dalam perubahan masyarakat di berbagai bidang, baik pendidikan, ekonomi, politik, sosial, budaya, dan teknologi informasi. Peran pesantren yang demikian kuat dikokohkan dalam undang-undang Nomor 18 Tahun 2019 tentang Pesantren yang

\footnotetext{
${ }^{5}$ Laporan Sudirman Mamad berjudul "Santri di Pusaran Revolusi Industri 4.0 dan Ancaman PHK" dalam situs:

https://finance.detik.com/industri/d-4479233/santri-di-pusaran-revolusi-industri-40-dan-ancamanphk Edisi 22 Maret 2019

6 Laporan Nugroho Habibi berjudul "Pesantren Manfaatkan 4.0 Faktor Penopang Pembelajaran" dalam https://www.republika.co.id/berita/dunia-islam/islam-nusantara/ppuaen320/pesantren-manfaatkan40-faktor-penopang-pembelajaran Edisi 12 April 2019

7 https://www.republika.co.id/berita/dunia-islam/islam-nusantara/ppuaen320/pesantren-manfaatkan40-faktor-penopang-pembelajaran Edisi 12 April 2019
} 
menyatakan bahwa ruang lingkup fungsi pesantren adalah pendidikan, dakwah, dan pemberdayaan masyarakat ${ }^{8}$.

Selama ini pondok pesantren dikenal sebagai institusi pendidikan khas Islam Indonesia dengan corak Islam rahmatan lil alamin. Berbagai upaya menyudutkan ajaran Islam di pesantren dengan isu-isu kekerasan berlatar agama, seperti radikalisme dan terorisme gagal dilakukan. Pondok pesantren melalui fungsi pendidikan, dakwah, dan pemberdayaan masyarakat justru mampu melawan narasi negatif tersebut meskipun seringkali dikaitkan dengan "radikalisme Islam" dalam berbagai pemberitaan media massa. Pesantren mampu membuktikan dan melawan pencitraan buruk tersebut melalui ajaran Islam yang ramah ${ }^{9}$.

Kedua, pondok pesantren mampu memerankan diri sebagai benteng moralitas bangsa dengan menyiapkan sumber daya santri yang siap menghadapi globalisasi zaman dengan menanamkan akhlaq generasi. Kemampuan pesantren sebagai kekuatan moralitas ini didukung dengan makin meningkatnya jumlah pondok pesantren di Indonesia yang mengajarkan Islam rahmatan lil alamin. Berdasarkan data Kementerian Agama tahun 2016, pesantren di nusantara berjumlah 28.194 lembaga dengan jumlah santri yang mencapai 4.290 .626 buah $^{10}$.

Keberadaan ribuan pondok pesantren dengan jutaan santrinya di nusantara ini memiliki peran yang sangat penting ketika bangsa Indonesia menghadapi penyebaran pandemi Covid-19. Ada tiga tindakan komunikasi pesantren dalam melawan Covid-19 di saat new normal. Pertama, pondok pesantren di Indonesia berbeda-beda dalam memaknai pesan penerapan new normal. Hal ini dapat dilihat dari keputusan pondok pesantren yang tidak sama didalam mengembalikan para santri mereka di lingkungan pondok pesantren. Kedua, para kyai pondok pondok pesantren mendukung pelaksanaan new normal dengan menerapkan protokol kesehatan yang ketat saat santri melaksanakan kegiatan di pesantren. Ketiga,

\footnotetext{
8 Didik Hariyadi Santoso, dkk, Media, Komunikasi dan Informasi di Masa Pandemi Covid-19 (Yogyakarta: MBridge Press, 2020), 255.

${ }^{9}$ Kun Wazis, Konstruksi realitas semu mengenai isu terorisme-radikalisme terhadap pondok pesantren (Jurnal Kajian Komunikasi Fikom Unpad, Vol. 8, No. 1 Juni 2020), diakses melalui http://jurnal.unpad.ac.id/jkk/article/view/25461/13420

10 Muhyiddin. (2017). Pertumbuhan Pesantren di Indonesia Dinilai Menakjubkan. Republika Online, 30 November<https://www.republika.co.id/berita/duniaislam/islamnusantara/17/11/30/p088lk396pertumbuhan-pesantren-di-indonesia-dinilai-menakjubkan> diakses 25 Juni 2020
} 
komunikasi pesantren dilakukan melalui saluran komunikasi media online dan media sosial yang dimiliki oleh pesantren ${ }^{11}$.

Ketiga, pondok pesantren menjadi perhatian penentu kebijakan, dalam hal ini pemerintah dengan mengeluarkan regulasi terkait pondok pesantren, diantaranya Kementerian Agama Republik Indonesia melalui Direktorat Pendidikan Diniyah dan Pondok Pesantren ${ }^{12}$, penetapan Hari Santri Nasional 22 Oktober, hingga lahirnya Undang-Undang Pondok Pesantren. Menurut Soebahar ${ }^{13}$ lahirnya UU Pesantren itu akan memberikan banyak peluang yang dapat diraih pesantren. Peluang pertama, dana abadi pesantren akan mudah di akses. Kejelasan dana investasi harus menunggu Peraturan Presiden tentang Dana Abadi Pesantren sebagaimana amanat pasal 49 UU Pesantren. Peluang kedua, akses pengembangan SDM dan kelembagaan pesantren melalui Pendidikan Diniyah Formal, Mu'adalah, Ma'had Aly, One Product One Pesantren, dan sebagainya. Dengan UU Pesantren akses pembiayaan menjadi terbuka, dengan UU Pesantren akses studi lanjut dan pekerjaan terbuka luas.

Keempat, kehidupan pondok pesantren menjadi kajian ilmiah di berbagai lembaga intelektual, baik jenjang S1, S2, dan S3 dari beragam perspektif sehingga melahirkan dinamika keilmuan, diantaranya pendidikan pondok pesantren, manajemen pesantren, ekonomi pesantren, budaya pesantren, politik pesantren, hingga komunikasi pesantren. Diantaranya bukti empiris dalam kajian ilmiah ini adalah riset Ahmadi ${ }^{14}$ yang menunjukkan adanya pola komunikasi kontingensi berbasis spiritualitas yang diterapkan kiai dalam mengintegrasikan budaya pesantren dan budaya Dayak. Pola ini merupakan penggabungan pola komunikasi publisitas satu arah, pola komunikasi transaksional yang kooperatif, terbuka dan

\footnotetext{
${ }^{11}$ Didik Hariyadi Santoso, dkk, Media, Komunikasi dan Informasi di Masa Pandemi Covid-19 (Yogyakarta: MBridge Press, 2020), 259.

12 Seiring dengan berkembangnya pembinaan dan pengorganisasian Direktorat Jenderal Kelembagaan Agama Islam yang berubah menjadi Direktorat Jenderal Pendidikan Islam, Direktorat Pendidikan Keagamaan dan Pondok Pesantren berubah pula menjadi Direktorat Pendidikan Diniyah dan Pondok Pesantren. Perubahan itu berdasarkan Peraturan Menteri Agama RI Nomor 3 Tahun 2006 sebagai tindak lanjut dari Peraturan Presiden Republik Indonesia Nomor 63 Tahun 2005 tentang Perubahan Peraturan Presiden Nomor 10 Tahun 2005. Lihat https://ditpdpontren.kemenag.go.id/web/sejarah/

${ }^{13}$ Halim Soebahar, Tantangan Baru Pasca UU Pesantren (Jember: Radar Jember Online, 25 Noemver 2019) diakses melalui https://radarjember.jawapos.com/perspektif-halim/25/11/2019/tantangan-barupasca-uu-pesantren/

${ }^{14}$ Ahmadi, Kepemimpinan Kiai dalam Membangun Komunikasi dan Komitmen Integrasi Budaya di Pondok Pesantren Hidayatul Insan Fii Ta'limiddin Kota Palangkaraya (Ringkasan Disertasi Pascasarjana IAIN Jember, 2020), 45.
} 
partisipatif, serta pola komunikasi transmisi. Pola ini mencerminkan komunikasi yang variatif, situasional dengan didasari nilai-nilai keagamaan.

Kajian mengenai komunikasi dan pesantren dapat dicermati dari penelitian Hadiono ${ }^{15}$ yang menjelaskan tentang manajemen radio dakwah pondok pesantren di Banyuwangi Jawa Timur. Sebagai institusi yang mengajarkan agama Islam, pondok pesantren juga mengembangkan komunikasi dakwah melalui media komunikasi radio yang dapat menjangkau khalayak luas. Hal ini menunjukkan bahwa institusi pondok pesantren tidak ketinggalan dengan media komunikasi. Dan, pada perkembangan era Revolusi Industri 4.0, sejumlah pondok pesantren di Indonesia juga mengembangkan media komunikasi pesantren yang dikelola dengan manajemen yang sangat baik, diantaranya pondok pesantren Sidogiri Pasuruan yang secara khusus memiliki Badan Pers Pesantren (BPP) untuk mengelola media massa di lingkungan pesantren ${ }^{16}$.

Realitas kajian daam bidang keilmuan komunikasi mengalami perkembangan yang dinamis pada era Revolusi Industri 4.0. Pandangan Panuju ${ }^{17}$ menyebut kajian komunikasi pesantren termasuk dalam ranah komunikasi kontemporer yang muncul bersama dengan bidang komunikasi lainnya, yakni komunikasi bisnis/ perusahaan, komunikasi internasional, komunikasi spiritual, komunikasi transcendental, komunikasi peradaban, komunikasi antar agama, komunikasi masjid, komunikasi kesehatan, komunikasi pendidikan, komunikasi kriminal, komunikasi terminal, dan komunikasi terpidana.

Berdasarkan fenomena tersebut, menurut penulis, kajian komunikasi yang terkait dengan dunia pesantren menarik untuk diteliti melalui perspektif komunikasi. Sebab, aktivitas yang menyangkut dan berkaitan realitas pondok pesantren diliputi dengan simbol-simbol maupun pesan-pesan komunikasi yang melahirkan makna-makna penting bagi kehidupan komunikasi umat manusia. Terlebih lagi, pondok pesantren sudah diketahui secara jamak peran besar dan kontribusinya dalam membangun peradaban bangsa sejak negara Indonesia belum lahir hingga negara Indonesia memasuki usia ke 75 tahun pada tahun 2020 ini.

\footnotetext{
15 Abdi Fauji Hadiono, Manajemen Radio Dakwah Al Hikmah Pondok Pesantren Imam Syafi'i Genteng Banyuwangi (Jurnal IJIC Pascasarjana IAIN Jember Vol 2, No. 1, Juli 2019), diakses melalui http://jurnalpasca.iain-jember.ac.id/ejournal/index.php/IJIC/article/view/407/48

16 Muhibbin, dkk., Pesantren dan Imperialisme Media (Laporan Penelitian Dosen IAIN Jember 2019), 6164. Diakses melalui http://lppm.iain-jember.ac.id/page/detail/penelitian-dosen-iain-jember

17 Redi Panuju, Pengantar Studi Ilmu Komunikasi (Jakarta: Prenada Media Group, 2018), 19.
} 


\section{B. PEMBAHASAN}

Kajian dalam artikel ini merupakan penelitian deskriptif dengan menggunakan studi pustaka (literature study) dengan memfokuskan pada dua dimensi penting. Pertama, mendeskripsikan keluasan ilmu komunikasi yang dapat mencakup berbagai objek dan subyek kajian, termasuk didalamnya adalah komunitas masyarakat pesantren di Indonesia yang pada tahun 2016 jumlahnya mencapai 28.149 institusi pondok pesantren. Literatur sebagai data pendukung yang dianalisis secara deskriptif adalah pandangan ilmuwan komunikasi yang menyatakan bahwa komunikasi mampu sebagai subyek keilmuan yang mampu menjangkau banyak bidang, termasuk obyek institusi pondok pesantren di Indonesia, maupun di berbagai negara lainnya (nusantara).

Kedua, menganalisis secara deskriptif komunikasi pesantren ${ }^{18}$ sebagai bidang kajian baru dalam konteks komunikasi. Dalam hal ini, penulis akan membuktikan secara ilmiah bahwa komunikasi pesantren dapat digunakan untuk membaca realitas pondok pesantren, baik dari perspektif positivistik, konstruktivis, maupun kritis. Kajian komunikasi pesantren dapat pula memahami makna pesan komunikator kyai kepada komunikan santri, pesan yang ditampilkan dalam media komunikasi pesantren, komunikasi politik kyai, komunikasi antarbudaya dalam komunitas pesantren ${ }^{19}$.

Fokus permasalahan yang dipecahkan dalam kajian ini adalah bagaimana konsep komunikasi pesantren itu dapat diwacanakan sebagai varian bentuk komunikasi dalam konteks kajian komunikasi. Fokus ini diperoleh dengan melihat realitas ilmu komunikasi yang memiliki keluasan dalam menjangkau subyek dan obyek yang dikaji. Dalam hal ini pondok pesantren yang dianalisis meliputi subyek kyai, ustad, dan santri, sedangkan obyek yang dideskripsikan adalah pondok/ asrama, masjid, dan pembelajaran kitab kuning. Sebagai institusi pendidikan Islam khas Indonesia, ilmu komunikasi dapat mengkaji pesan-pesan komunikasi yang

\footnotetext{
${ }^{18}$ Kajian Komunikasi Pesantren ini pernah dipresentasikan oleh penulis dalam International Conference "Spirituality and Education for Civilization Sustainability in the IR 4.0 Era" yang digelar Pascasarjana IAIN Jember pada 7-8 September 2019.

19 Kajian tentang Jurnalisme Pesantren memfokuskan pada perlawanan media komunikasi pondok pesantren terhadap hegemoni media massa mainstream dalam mengkonstruksi realitas sosial di media massa. Lihat Minan Jauhari dan Muhibbin, Jurnalisme Pesantren dan Media Cyber: Membendung Hegemoni Media dari Bilik Pesantren. Jurnal Fenomena LP2M IAIN Jember Volume 16, Nomo 1 April 2016 dalam website http://ejournal.iain-jember.ac.id/index.php/fenomena/article/view/702/563
} 
muncul dari kehidupan pondok pesantren, baik yang terkait dengan subyek maupun obyeknya karena memiliki makna komunikasi tersendiri.

\section{Multidimensi Ilmu Komunikasi}

Kajian Ilmu komunikasi di Indonesia dapat dikatakan masih relatif baru. Dalam catatan Panuju ${ }^{20}$, kebaruan ilmu komunikasi itu bisa dilihat dari kajian-kajian sebelumnya yang menyangkut komunikasi masih terbatas pada bagaimana sebuah pesan disebarluaskan (publish). Karena itu, fakultas atau prodi yang menyelenggarakan kajian ini menamakan diri sebagai Fakultas Publistik atau Jurusan Publistik. Misalnya, di Universitas Indonesia (UI), Universitas Padjadjaran (Unpad), Universitas Gadjahmada (UGM), dan Universitas Hasanuddin (Unhas). Pada tahun 1982-1983, nama Publistik resmi menjadi Ilmu Komunikasi. Memang ada noment klature yang berbeda. Di Unpad dalam bentuk fakultas (Fakultas Ilmu Komunikasi disingkat Fikom) sedang di UGM dan UI dalam bentuk jurusan Ilmu Komunikasi di bawah Fakultas Ilmu Sosial dan Ilmu Politik.

Fenomena ilmu komunikasi bergerak dinamis dari waktu ke waktu seiring dengan perkembangan berfikir para ilmuwan komunikasi. Sebagaimana digambarkan guru besar ilmu komunikasi Universitas Padjadjaran Bandung Indonesia Deddy Mulyana dalam Hamid ${ }^{21}$, bahwa ilmu komunikasi adalah suatu konstruksi yang dibuat oleh manusia, seperti tanah liat yang dapat dibentuk apa saja atau air yang dapat memenuhi wadah yang bagaimanapun bentuknya. Mulyana menyatakan:

“Bagaimana definisi komunikasi atau modelnya (secara implisit juga unsurunsurnya), bagaimana bentuk, konteks atau bidang, dan bagaimana cara menelitinya, mata kuliah apa dan konsentrasi atau program studi atau jurusan apa, dapat dan akan terus berubah, selaras dengan perkembangan peradaban manusia dan kemajuan teknologi komunikasi".

Menurut Mulyana, dewasa ini terjadi konvergensi berbagai bidang ilmu, bukan hanya antara ilmu-ilmu yang selama ini bersifat sosial, tetapi juga antara ilmu sosial dan ilmu-ilmu yang selama ini dikategorikan ilmu pasti alam (IPA), seperti kedokteran, fisika, dan arsitektur. Maka, muncullah mata kuliah bernama:

\footnotetext{
${ }^{20}$ Redi Panuju, Pengantar Studi Komunikasi (Jakarta: Prenadamedia Group, 2018),

21 Deddy Mulyana, Mau Kemana Ilmu Komunikasi Kita dalam Farid Hamid, Heri Budianto (ed), Ilmu Komunikasi: Sekarang dan Tantangan Masa Depan (Jakarta: Kencana Prenada Media Group, 2011 ), 2. Lihat Kun Wazis, Komunikasi Tiga Dimensi (Jember: Jurnal Al Adalah Vol. 19, No. 1, Mei 2016), 167-189.
} 
komunikasi kesehatan, antropologi arsitektur, psikologi agama, dan sosiofisika. Selama satu-dua dekade terakhir ini dan apa lagi pada masa yang akan datang, batasan ilmu akan semakin cair, karena semakin rumitnya kehidupan manusia.

Pakar ilmu komunikasi di Indonesia yang lain membenarkan keluasan perspektif ilmu komunikasi ini. Menurut Cangara ${ }^{22}$, sebagai ilmu, komunikasi merupakan kumpulan pengetahuan yang disusun secara sistematis berdasarkan fakta dan riset. Ia melakukan penyelidikan masalah, kontrol, dan pengujian menurut kaidah-kaidah ilmiah dan secara normatif hasilnya dapat disajikan dan diterapkan untuk menciptakan dan membina tatanan hidup manusia agar menjadi lebih baik dalam pribadi maupun dalam hidup bermasyarakat.

Gambaran ilmu komunikasi sebagaimana dikemukakan Mulyana dan Cangara diperkuat dengan realitas empiris bahwa ilmu komunikasi bersifat multidisiplin. Arifin $^{23}$ menyatakan bahwa banyak ilmuwan dari berbagai disiplin yang telah memberikan sumbangan kepada ilmu komunikasi, antara lain Harold D. Lasswell (Politik), Max Weber, Daniel Larner, dan Everett M. Rogers (Sosiologi), Carl I. Hoveland dan Paul Lazarsfeld (Psikologi), Wilbur Schramm (bahasa), Shannon dan Weaver (Matematika dan Teknik). Tidak mengherankan jika banyak disiplin telah terlibat dalam studi komunikasi baik secara langsung, maupun tidak langsung. Arifin mengutip Fisher $(1986,17)$ yang menyatakan bahwa komunikasi memang mencakup semuanya, dan bersifat sangat eklektif (menggabungkan berbagai bidang $)^{24}$.

Menurut Morisan ${ }^{25}$, perkembangan teknologi komunikasi mutakhir belakangan ini menyebabkan upaya merumuskan definisi ilmu komunikasi menjadi lebih sulit dilakukan. Perkembangan teknologi telah semakin mengaburkan garis batas yang membedakan antara komunikasi publik dan komunikasi pribadi, serta antara komunikasi massa dan komunikasi interpersonal. Saat ini, sudah tidak mungkin lagi untuk menemukan satu definisi ilmu komunikasi yang dapat

\footnotetext{
22 Hafied Cangara, Pengantar Ilmu Komunikasi (Jakarta: RajaGrafindo Persada, 2004), 11

23 Anwar Arifin, Ilmu Komunikasi (Jakarta: RajaGrafindo Persada, 2003). 14-15

24 Bidang kajian komunikasi yang cukup beragam dapat ditemukan dalam kajian komunikasi politik, komunikasi antarbudaya, komunikasi terapeutik, komunikasi kesehatan, komunikasi bisnis, komunikasi organisasi, komunikasi peradaban, komunikasi Islam, komunikasi internasional, komunikasi pemerintahan, komunikasi pendidikan, dan sebagainya. Hal ini memungkinkan melahirkan komunikasi pesantren, diantaranya sebagai bidang kajian baru dalam memperkuat keilmuan komunikasi.

25 Morissan, Andy Corry Wardhani, Farid Hamid, Teori Komunikasi Massa (Bogor: Ghalia Indonesia, 2010), 6
} 
menjelaskan secara lengkap berbagai perbedaan fenomena dan perspektif komunikasi. Ilmu komunikasi juga tidak mungkin berdiri sendiri (independen), mengingat asal mula ilmu komunikasi adalah dari berbagai disiplin ilmu pengetahuan, seperti ekonomi, hukum, politik, etik, dan kebudayaan.

Berdasarkan penjelasan tersebut, dunia komunikasi yang mempelajari pernyataan manusia juga akan mengalami dinamika yang luas karena kegiatan komunikasi dipengaruhi banyak hal, terutama perkembangan teknologi komunikasi. Misalnya, kegiatan komunikasi ketika belum ada internet dan saat manusia menggunakan internet akan berbeda karakteristiknya; pernyataan manusia dalam berkomunikasi yang dipengaruhi teknologi komunikasi akan menemukan ciri khasnya. Mendasarkan pada konteks kajian komunikasi yang multidimensi, maka komunikasi pesantren $^{26}$ dapat diposisikan sebagai varian kajian komunikasi baru dengan mendasarkan pada kelayakan bidang yang dikaji.

\section{Dimensi Komunikasi Pesantren}

Memaknai komunikasi pesantren tidak bisa dilepaskan dari kerangka memahami arti komunikasi. Pandangan Mulyana ${ }^{27}$ mengungkapkan tiga kerangka pemahaman mengenai komunikasi dengan mendasarkan pandangan John R. Wenburg dan Willia W. Wilot, Kenneth K. Sereno dan Edward Bodaken, yaitu komunikasi sebagai tindakan satu arah, komunikasi sebagai interaksi, dan komunikasi sebagai transaksi.

Pertama, suatu pemahaman populer mengenai komunikasi manusia adalah komunikasi yang mengisyaratkan penyampaian pesan searah dari seseorang (atau suatu lembaga) kepada seseorang (sekelompok orang) lainnya, baik secara langsung (tatap-muka) ataupun melalui media, seperti surat (selebaran), surat kabar, majalah, radio, atau televisi. Kedua, pandangan komunikasi sebagai interaksi menyetarakan komunikasi dengan proses sebab akibat atau aksi-reaksi, yang arahnya bergantian.

\footnotetext{
26 Sebagai bidang kajian, komunikasi pesantren memfokuskan kajian pada elemen-elemen pondok pesantren. Komunikasi pesantren ini tidak bisa lepas dari "identitas utama" sebuah pondok pesantren yang jika didekati dengan model komunikasi Laswell terdiri atas komunikator (communicator) kyai, komunikan (communicant) santri, pesan (message) kitab kuning, sarana (media/ channel) masjid/ madrasah, dan dampak (effect) dari kehidupan dunia pesantren terhadap dunia luarnya. Persentuhan komunikasi pesantren ini menegaskan bahwa Islam bisa menerima komunikasi yang akar keilmuannya dari Barat dengan tanpa meninggalkan nilai-nilai ajaran Islam yang dikembangkan oleh pondok pesantren. Lihat Kun Wazis, Memaknai Komunikasi Pesantren dalam Koran Jawa Pos Radar Jember Edisi Jumat 24 Mei 2019, dan dipublikasikan dalam website https://radarjember.jawapos.com/2019/05/23/memaknai-komunikasi-pesantren/

27 Deddy Mulyana, Ilmu Komunikasi Suatu Pengantar (Bandung: Remaja Rosdakarya, 2014), 67-77.
} 
Seseorang menyampaikan pesan, baik verbal atau nonverbal, seorang penerima bereaksi dengan memberi jawaban verbal atau menganggukkan kepala, kemudian orang pertama bereaksi lagi setelah menerima respons atau umpan balik dari orang kedua, dan begitu seterusnya. Ketiga, komunikasi sebagai transaksi adalah proses personal karena makna atau pesan yang kita peroleh pada dasarnya bersifat pribadi. Hingga derajat tertentu para pelakunya sadar akan kehadiran orang lain di dekatnya dan bahwa komunikasi sedang berlangsung, meskipun pelaku tidak dapat mengontrol sepenuhnya bagaimana orang lain menafsirkan perilaku verbal dan nonverbalnya.

Mendasarkan pada tiga kerangka pemahaman itu, komunikasi pesantren terkait erat dengan proses penyampaikan pesan ajaran Islam yang dilakukan oleh komunikator, yakni kyai atau ustad kepada para santrinya melalui media pembelajaran pesantren, seperti sorogan atau wetonan ${ }^{28}$ yang bertujuan membentuk perilaku Islami agar memberikan manfaat kepada masyarakat luas. Dalam hal interaksi penyampaian pesan selama kehidupan pondok pesantren, baik kyai, ustad, santri, dan masyarakat di luar pondok pesantren terjadi proses timbal balik dari pesan yang diterima. Pada dimensi pemaknaan pesan, setiap komunikator (kyai, ustad) maupun komunikan (santri) yang terlibat dalam proses penerimaan maupun penyampaian pesan memiliki makna yang berbeda-berbeda.

Menurut Effendy ${ }^{29}$, memahami komunikasi tidak bisa dilepaskan dari paradigma Laswell melalui karyanya "The Structure and Function of Communication in Society" yang menunjukkan bahwa komunikasi meliputi lima unsur, yakni: 1) komunikator (communicator, source, sender); 2) pesan (message); 3) media (channel, media); 4) komunikan (communicant, communicatee, reciever, recipient); dan 5) efek (effect, impact, influence). Berdasarkan paradigm Laswell, komunikasi adalah proses penyampaian pesan oleh komunikator kepada komunikan melalui media yang menimbulkan efek tertentu. Laswell menghendaki agar komunikasi dijadikan objek studi ilmiah, bahkan setiap unsur diteliti secara khusus. Studi mengenai

\footnotetext{
${ }^{28}$ Metode yang diterapkan pondok pesantren dalam mempelajari kitab kuning adalah metode hafalan, wetonan-bandongan, metode sorogan, dan metode mudzakarah. Lebih lengkap baca Babun Suharto, Dari Pesantren untuk Umat (Surabaya: Imtiyaz, 2011), 122.

29 Onong Uchjana Effendy, Ilmu Komunikasi: Teori dan Praktek (Bandung: Rosdakarya, 2003), 10. Ditegaskan bahwa komunikasi adalah ilmu, dan ilmu komunikasi ini termasuk kedalam ilmu sosial yang meliputi intrapersonal communications, interpersonal communications, group communications, mass communications, intercultural communications, dan sebagainya
} 
komunikator dinamakan control analysis; penelitian mengenai pers, radio, televisi, film, dan media lainnnya disebut media analysis; penyelidikan mengenai pesan dinamai content analysis; audience analysis adalah studi khusus tentang komunikan; sedangkan effect analysis merupakan penelitian mengenai efek atau dampak yang ditimbulkan oleh komunikasi.

Implikasi kajian komunikasi Laswell ini jika dikaitkan dengan konteks pesantren, maka risetnya sudah dikembangkan oleh sejumlah peneliti di Indonesia. Diantaranya, riset komunikator meneliti tentang bagaimana komunikator kyai menyampaikan pesan kepada para santrinya, mulai dari gaya hingga model komunikasi kyai. Demikian juga sebaliknya, respon santri terhadap pesan dakwah kyai juga ditemukan dalam banyak riset, baik di jenjang S1, S2, dan S3.

Analisis media juga sudah banyak dikembangkan oleh sejumlah peneliti, khusus meneliti wacana-wacana yang dikembangkan oleh pesantren melalui media online pesantren. Analisis framing terhadap konstruksi media pesantren bisa diteliti seiring meningkatnya penggunaan media komunikasi, terutama media online pondok pesantren yang dibuat oleh pesantren. Selain itu, juga dapat difokuskan pada media massa umum yang mengonstruksi realitas pesan dapat diteliti melalui analisis media ini. Jika difokuskan pada isi pesan pesan, maka pesan-pesan dakwah kaum pesantren dapat didekati dari sisi wacana maupun framing.

Riset terhadap pondok pesantren ini juga tidak lepas dari pandangan Laswell tentang "Who says what in which channel to whom with what effcet" yang dijabarkan oleh Kriyantono ${ }^{30}$ kedalam kualifikasi riset komunikasi yang mencakup: a) studi komunikator (who), yaitu studi mengenai komunikator sebagai individu maupun institusi. Contoh: riset mengenai kredibilitas Radio Suara Surabaya dalam menginformasikan berita kriminal; b) studi pesan (says what), yaitu studi mengenai isi pesan, analisis teks, semiotik, pesan verbal maupun nonverbal, copy-testing untuk iklan atau analisis program Public Relation (PR). Contoh: riset tentang penggunaan bahasa Suroboyoan dalam acara berita Pojok Kampung JTV; c) studi media (in which channel), yaitu studi mengenai medianya (salurannya). Contoh, studi tentang proses pembuatan berita di meja redaksi dan proses manajemen media; d) studi khalayak (to whom), yaitu studi mengenai khalayak atau komunikan. Contoh: riset tentang

30 Rachmat Kriyantono, Teknik Praktis Riset Komunikasi (Jakarta: Kencana Prenada Media Group, 2012), 12-13. 
opini, profil, uses \& gratifications, agenda setting maupun focus group discussion (FGD); e) studi efek (with what effect), yaitu studi mengenai efek terpaan pesan. Efek adalah dampak dari terpaan pesan komunikasi. Contoh: riset mengenai efek terpaan iklan terhadap motif membeli produk dan efek dari program kampanye Safety-riding Polda Jatim.

Pandangan Kriyantono tersebut dapat dikonteksnya dengan institusi pondok pesantren di Indonesia. Diantaranya, untuk studi komunikator bisa dikembangkan pada riset tentang kredibilitas kyai dalam menyampaikan dakwah Islam ramah kepada masyarakat sekitar, strategi komunikasi pesantren dalam menanggulangi paham radikalisme, model komunikasi dakwah santri di era digital, dan sebagainya. Untuk studi pesan, dapat meneliti pesan verbal non verbal santri dalam memasarkan produk bisnis pesantren, iklan air minum produk pesantren, analisis teks berita radikalisme di media online pesantren, dan sejenisnya. Untuk studi media, bisa meneliti manajemen redaksi media dakwah pesantren, proses jurnalistik berita pesantren, dan strategi komunikasi redaksi media pesantren dalam menyajikan informasi kegiatan pesantren. Untuk studi khalayak, dapat meneliti analisis resepsi penerima santri terhadap iklan rokok di media massa, respon kaum pesantren terhadap isu radikalisme dan terorisme, dan sebagainya. Untuk studi efek, dapat meneliti pengaruh kepemimpinan kyai dalam meningkatkan kualitas pendidikan pondok pesantren, pengaruh media pesantren terhadap perilaku santri, dan sejenisnya.

Pemaknaan tersebut dapat diarahkan pada subyek komunikasi dan obyek pesantren yang mengkaji kehidupan komunikasi orang-orang yang berada di lingkungan pesantren melalui simbol-simbol yang dipertukarkan dalam meraih makna atau tertentu. Simbol dan pesan komunikasi itu dapat diteliti dari lima elemen pondok pesantren sebagaimana dinyatakan Dhofier ${ }^{31}$ sehingga dapat dimaknai melalui pesan komunikasi.

Pertama, pondok merupakan asrama yang menjadi tempat tinggal santri selama mereka mendalami ajaran Islam yang diasuh oleh seorang kyai. Pondok atau asrama merupakan sarana (media/ saluran) bertemunya santri dari berbagai latar belakang yang berbeda. Komunikasi antarsantri selama 24 jam di bawah

31 Lihat Zamakhsyari Dhofier, Tradisi Pesantren, Studi tentang Pandangan Hidup Kiai (Jakarta: LP3ES, 2011), 79-93 
pengawasan kyai atau ustad dapat diteliti dari perspektif komunikasi antarbudaya dalam memahami komunikasi para santri yang biasanya berasal dari berbagai daerah yang berbeda budaya. Sebagian pesantren juga menerima santri dari luar negeri. Dalam konteks komunikasi, pola komunikasi para santri berbeda budaya dapat menjadi temuan yang menarik sebagai riset berbasis komunikasi ${ }^{32}$.

Pada era revolusi industri $4.0 \mathrm{ini}$, sejumlah pondok pesantren di Indonesia menjadikan saluran komunikasi teknologi berbasis internet sebagai media untuk menyampaikan pesan-pesan ajaran pesantren di ruang publik. Untuk itu, dengan menelusuri dari mesin pencari informasi Google dengan melakukan klik kata "pondok pesantren" akan mudah ditemukan beragam nama pondok pesantren di Indonesia. Maknanya, komunikasi melalui media direspon oleh kalangan pondok pesantren untuk menampilkan identitas pesantren di ruang publik ${ }^{33}$.

Kedua, masjid yang wajib ada dalam sebuah pesantren biasanya menjadi tempat utama dalam kegiatan peribadahan, seperti shalat lima waktu, shalat-shalat sunnah, pembelajaran kitab-kitab Islam klasik (sering disebut kitab kuning), latihan retorika bagi santri (muhadlarah), khutbah dan shalat jumat, istighotsah, dzikir, membaca Al Qur'an, dan aktivitas religius lainnya. Disamping itu, simbol-simbol yang ditampilkan di ruang masjid, mulai dari bentuk kubah, arsitektur masjid, tata letak masjid, hingga ornamen bangunan masjid di pesantren dapat dianalisis dari sisi wacana teksnya.

Dalam konteks komunikasi, masjid adalah simbol bagi umat Islam dalam komunikasi transedental, yakni komunikasi yang berkaitan dengan nilai-nilai spiritualitas. Dapat pula, kegiatan itu termasuk tindakan komunikasi intrapersonal sebagai sarana berkomunikasi santri dengan dirinya sendiri. Karena masjid juga menunjukkan peradaban, maka komunikasi peradaban dapat menjadi salah fokus penelitian di pondok pesantren. Komunikasi pendidikan dalam lembaga pendidikan

\footnotetext{
32 Perjumpaan santri dari berbagai daerah yang berbeda budaya menjadi kajian komunikasi transbudaya. Pola-pola komunikasi santri berbeda budaya yang berada dalam lingkungan pesantren mendidik santri untuk saling memahami perbedaan-perbedaan budaya sehingga memperkuat toleransi. Lihat Kun Wazis. 2017. Komunikasi Transbudaya Pondok Pesantren: Kajian Teoritis dalam Paradigma Konstruktivis. Jurnal Lugas STIAMI Jakarta, Volume 1, Nomor 01, 2017, diakses melalui https://ojs.stiami.ac.id/index.php/lugas/article/view/106/94

33 Penelusuran melalui Google dapat memudahkan melacak identitas pondok pesantren di Indonesia dengan beragam karakteristiknya. Profil pesantren juga dapat diakses lebih detil. Lihat ttps://www.google.com/search?q=pondok+pesantren\&oq=pondok+pesantren\&aqs=chrome..69i57j69i 61j69i60j69i61.6484j0j8\&sourceid=chrome\&ie=UTF-8
} 
pesantren dapat diteliti dari berbagai aspek, diantaranya model komunikasi ustadz dan santri dalam pembelajaran tertentu.

Saluran/ media untuk menyampaikan dalam perkembangannya tidak hanya dibatasi dalam ruang masjid. Pondok pesantren juga beradaptasi dengan teknologi informasi yang bergerak masif. Diantaranya, mengikuti perkembangan revolusi industri 4.0 yang meniscayakan penggunaan perangkat berbasis jaringan internet untuk kegiatan komunikasi di pesantren ${ }^{34}$.

Ketiga, pengajaran kitab Islam klasik. Sebagaimana dinyatakan Dhofier, pada masa lalu, pengajaran kitab Islam klasik, terutama karangan-karangan ulama yang menganut faham Syafi'i, merupakan satu-satunya pengajaran formal yang diberikan dalam lingkungan pesantren. Tujuan utamanya ialah untuk mendidik calon-calon ulama. Para santri yang tinggal di pesantren untuk jangka waktu pendek (misalnya kurang dari satu tahun) dan tidak bercita-cita menjadi ulama, bertujuan untuk mencari pengalaman dan pendalaman perasaan keagamaan. Sumber-sumber utama yang menjadi rujukan para ulama nusantara yang menjadi pengarang kitab klasik dapat dianalisis dari sisi teks yang diwacanakan.

Dalam konteks kekinian, lembaga pendidikan pondok pesantren tidak hanya mengajarkan kitab-kitab klasik, tetapi mengembangkan manajemen pendidikan mereka melalui sekolah maupun perguruan tinggi yang bersifat formal, diantaranya MI/ SD, MTs/ SMP, MA/ SMK/ SMA, hingga Ma'had Aly/ Perguruan Tinggi. Pesantren memadukan konteks pendidikan agama Islam dengan ilmu-ilmu umum sehingga menampilkan karakteristik simbolik yang berbeda dengan model pesantren yang bersifat tradisional (salaf). Melalui UU Pesantren pula, posisi pesantren akan semakin kokoh dalam melaksanakan otonomi pendidikan dengan corak yang semakin khas.

Dinamika kehidupan pesantren yang sedemikian menarik adalah pesan komunikasi yang penuh dengan makna sehingga menjadi penting untuk digali. Pondok pesantren yang saat ini menampilkan corak pendidikannya melalui berbagai media komunikasi dapat diteliti. Diantaranya, pondok pesantren klasik ikut

\footnotetext{
34 Pondok pesantren mudah beradaptasi dalam merespon perkembangan teknologi dan informasi. Meskipun menimbulkan permasalahan baru, tetapi pondok pesantren memiliki perspektif yang khas dalam menyikapinya. Lihat Nilna Azizatus Shofiyyah, Haidir Ali, dan Nurhayati Sastraatmadja. 2019. Model Pondok Pesantren di Era Milenial. STAIN Curup: Belajea, Jurnal Pendidikan Islam, Vol. 4, No. 1, 2019; $1-18$
} 
mengembangkan model komunikasi modern berbasis media massa, baik media cetak, media elektronik, dan media online ${ }^{35}$.

Keempat, santri adalah "murid" yang secara berniat mempelajari ilmu agama Islam di pondok pesantren. Biasanya, terdapat dua jenis santri yang berada di suatu pondok pesantren, yakni santri yang menetap (mukim) dan santri kalong (tidak tinggal di pesantren dan hanya saat belajar agama mereka berada di pondok pesantren). Model pembelajaran dapat berupa sorogan dan bandongan serta model pembelajaran lain yang ditetapkan oleh pengurus pondok pesantren. Penerimaan santri dalam menyerap informasi dari ustad saat pembelajaran dapat dikaji dari sisi respon. Termasuk kajian respon santri atas modernitas maupun peran santri dalam birokrasi yang mulai banyak dimasuki santri setelah mereka terjun ke dunia politik.

Komunikasi antara santri dengan kyai, santri dengan ustad, santri dengan santri dalam kehidupan lingkungan pondok pesantren merupakan fenomena komunikasi yang menarik untuk diteliti. Model-model komunikasi santri dengan kyai, dapat didalami melalui berbagai perspektif dan teoritis. Kajian-kajian yang bersifat fenomenologis, yakni pengalaman sadar santri dalam memaknai kehidupan pondok pesantren dapat dijadikan riset yang menarik ${ }^{36}$. Termasuk, bagaimana strategi komunikasi pesantren dalam menghadapi penyebaran Covid-19 di Indonesia dapat menjadi penelitian yang memberikan manfaat akademis.

Kelima, kyai adalah komunikator utama dalam pondok pesantren. Kyai merupakan figur penting dalam mewarnai seluruh kehidupan pondok pesantren, mulai dari santri, ustad, hingga pengembangan pondok pesantren. Munculnya kyai merupakan fenomena yang diperhitungkan oleh bangsa dalam melakukan perubahan masyarakat. Untuk itu, kyai biasanya tidak hanya dihormati dan ditaati oleh santri, ustad, alumni, dan wali santri, tetapi memiliki pengaruh luas dalam hal politik, ekonomi, sosial, dan budaya. Salah satu yang bisa menjelaskan hal ini adalah

35 Pesantren-pesantren salaf di Indonesia mengembangkan media komunikasi. Diantaranya, pondok pesantren Sidogiri mendirikan Badan Pers Pesantren (BPP) yang mengurusi penerbitan berbasis media informasi, misalnya melalui website resminya www.sidogiri.net. Pondok pesantren klasik di Tremas Pacitan, yakni Perguruan Islam Pondok Tremas Pacitan membuat website www.pondoktremas.com untuk menampilkan informasi berbasis pesantren. Dalam konteks komunikasi, dapat diteliti fenomena media komunikasi pesantren dengan berbagai perspektif, baik yang bersifat positivistik, konstruktivis, maupun kritis

${ }^{36}$ Komunikasi santri, kyai, dan ustad pondok pesantren merupakan fenomena komunikasi pesantren yang menarik diteliti. Misalnya, penelitian Rudi Hartono. 2016. Pola Komunikasi di Pesantren : Studi tentang Model Komunikasi antara Kiai, Ustadz, dan Santri di Pondok Pesantren TMI Al-Amien Prenduan. Jurnal Al Balagh, Vol. 1, No. 1, 2016 diakses http://ejournal.iainsurakarta.ac.id/index.php/albalagh/article/view/60 
riset yang terkait dengan kepemimpinan kyai di pesantren dan masyarakat, relasi kyai dan birokrasi, serta kyai dan politik.

Strategi komunikasi politik kyai adalah salah satu riset yang kini banyak dikembangkan dalam kajian komunikasi politik. Karena pada kenyataannya, banyak kyai yang kini terjun ke dunia politik, seperti pemerintahan, partai politik, maupun tim sukses politik dalam pemilihan umum. Selain itu, pola komunikasi kyai dan santri dalam pembelajaran atau pendidikan di pesantren juga terus diteliti sehingga ditemuka pola-pola komunikasi kyai dan santri yang khas, unik, dan mencirikan tradisi pesantren.

Dalam konteks komunikasi, model dan bentuk komunikasi para kyai ini menarik untuk diteliti, baik yang terkait dengan strategi komunikasi dalam mempertahankan identitas pesantren di tengah gempuran budaya modern, maupun model komunikasi yang selama ini dilakukan dalam relasi dengan kekuasaan. Perilaku tindakan komunikasi kyai terhadap santri dan ustad pesantren dapat memperkaya ilmu komunikasi ketika membaca pesan atau simbol-simbol yang dipertukarkan oleh kyai terhadap santrinya.

\section{KESIMPULAN DAN SARAN}

Berdasarkan penjelaskan diatas dapat ditarik suatu kesimpulan bahwa komunikasi pondok pesantren dapat menjadi varian bidang baru kajian komunikasi. Komunikasi pesantren merupakan proses penyampaian pesan komunikator, baik kyai maupun ustad kepada komunikan santri melalui media pembelajaran maupun media komunikasi lainnya yang bertujuan menyampaikan ajaran Islam rahmatan lil alamin melalui kitab-kitab kuning dalam rangka membentuk perilaku yang Islami. Ada dua kesimpulan penting dalam menandai kajian komunikasi pesantren tersebut. Pertama, komunikasi pesantren didukung oleh suatu kenyataan bahwa ilmu komunikasi mampu menjangkau bidang kajian yang luas, dalam hal ini menyentuh identitas pondok pesantren yang memiliki jaringan tidak hanya secara nasional, tetapi internasional melalui jaringan ulama nusantara. Varian kajian komunikasi pesantren pada satu sisi masih bisa disebut sebagai titik kelemahan mengingat komunikasi umum sudah menjangkau posisi pondok pesantren dengan kajian komunikasi sebelumnya, seperti komunikasi organisasi untuk melihat organisasi pesantren, maupun komunikasi politik untuk meriset komunikasi politik kyai. 
Kedua, komunitas pondok pesantren merupakan realitas simbolik yang memancarkan pesan-pesan komunikasi untuk selalu dideteksi maknanya melalui kehidupan pondok pesantren. Hal ini disebabkan pondok pesantren merupakan instituasi perubahan sosial yang telah terbuktinya nyata dalam mencerdaskan kehidupan bangsa melalui identitas pendidikan di pondok pesantren. Sebagai obyek kajian bidang komunikasi, simbol dan pesan yang dipertukarkan oleh komunitas pondok pesantren tidak bisa dihindari oleh ilmu komunikasi sebagai bidang ilmu yang mengkaji pernyataan-pernyataan manusia.

Dalam rangka meningkatkan kajian-kajian komunikasi pesantren, diperlukan penelitian-penelitian komunikasi yang lebih mendalam dengan beragam paradigma, baik perspektif positivistik, perspektif konstruktivis, maupun kritis. Kajian dapat pula dikembangkan melalui lembaga-lembaga riset, baik di tingkat perguruan tinggi umum maupun keagamaan yang berstatus negeri dan swasta pada jenjang S1, S2, dan S3. Dengan demikian, integrasi keilmuan antara ilmu komunikasi yang berbasis Barat dapat berjumpa dengan Ilmu Islam yang diajarkan di pondok-pondok pesantren untuk memperkaya khazanah keilmuan masing-masing $\left(^{*}\right)$

\section{DAFTAR PUSTAKA}

Ahmadi, 2020. Kepemimpinan Kiai dalam Membangun Komunikasi dan Komitmen Integrasi Budaya di Pondok Pesantren Hidayatul Insan Fii Ta'limiddin Kota Palangkaraya. Ringkasan Disertasi Pascasarjana IAIN Jember.

Arifin, Anwar. 2003. Ilmu Komunikasi. Jakarta: RajaGrafindo.

Cangara, Hafied. 2004. Pengantar Ilmu Komunikasi. Jakarta: Rajawali Pers.

Dhofier, Zamakhsyari. 2011. Tradisi Pesantren, Studi tentang Pandangan Hidup Kiai. Jakarta: LP3ES.

Effendy, Onong Uchjana. 2003. Ilmu Komunikasi: Teori dan Praktek. Bandung: Rosdakarya.

Eksan, Moch. 2009. Dari Bom Bali Sampai Kuningan. Jember: LPM Filantropy Studies dan Pena Salsabila.

Habibi, Nugroho. 2019. Pesantren Manfaatkan 4.0 Faktor Penopang Pembelajaran. https://www.republika.co.id/berita/dunia-islam/islamnusantara/ppuaen320/pesantren-manfaatkan-40-faktor-penopangpembelajaran Edisi 12 April 2019 
Hadiono, Abdi Fauji. 2019. Manajemen Radio Dakwah Al Hikmah Pondok Pesantren Imam Syafi'i Genteng Banyuwangi. Jurnal IJIC Pascasarjana IAIN Jember Vol 2, No. 1, Juli 2019), diakses melalui: http://jurnalpasca.iain-jember.ac.id/ ejournal/index.php/IJIC/article/view/407/48

Hamid, Farid, Heri Budianto. 2011. Ilmu Komunikasi: Sekarang dan Tantangan Masa Depan. Jakarta: Kencana Prenada Media Group.

Hartono, Rudi. 2016. Pola Komunikasi di Pesantren : Studi tentang Model Komunikasi antara Kiai, Ustadz, dan Santri di Pondok Pesantren TMI Al-Amien Prenduan. Jurnal Al Balagh, Vol. 1, No. 1, 2016 diakses:

http://ejournal.iainsurakarta.ac.id/index.php/al-balagh/article/view/60

http://binus.ac.id/knowledge/2019/05/mengenal-lebih-jauh-revolusi-industri-4-0/

https://www.google.com/search?q=pondok+pesantren\&oq=pondok+pesantren\&aqs

=chrome..69i57j69i61j69i60j69i61.6484j0j8\&sourceid=chrome\&ie=UTF-8

https://ditpdpontren.kemenag.go.id/web/sejarah/

Kriyantono, Rachmat. 2012. Teknik Praktis Riset Komunikasi. Jakarta: Kencana Prenada Media Group.

Muhibbin, dkk., 2019. Pesantren dan Imperialisme Media. Laporan Penelitian Dosen IAIN Jember 2019. Diakses melalui http://lppm.iainjember.ac.id/page/detail/penelitian-dosen-iain-jember

Mulyana, Deddy. 2014. Ilmu Komunikasi Suatu Pengantar. Bandung: Remaja Rosdakarya.

Nasvian, Moch Fuad, Bambang Dwi Prasetyo, dan Darsono Wisadirana. Model Komunikasi Kyai dengan Santri (Studi Fenomenologi pada Pondok Pesantren "Ribathi" Miftahul Ulum). Jurnal Wacana Universitas Brawijiaya Malang. https://www.neliti.com/id/publications/40097/model-komunikasi-kyaidengan-santri-studi-fenomenologi-pada-pondok-pesantren-rib

Jauhari, Minan dan Muhibbin. 2017. Jurnalisme Pesantren dan Media Cyber: Membendung Hegemoni Media dari Bilik Pesantren. Jurnal Fenomena LP2M IAIN Jember Vol. 16, No. 1 April 2016 dalam:

http://ejournal.iain-jember.ac.id/index.php/fenomena/article/view/702/563

Mamad. 2019. Sudirman. Santri di Pusaran Revolusi Industri 4.0 dan Ancaman PHK. https://finance.detik.com/industri/d-4479233/santri-di-pusaran-revolusiindustri-40-dan-ancaman-phk Edisi 22 Maret 2019 
Morissan, Andy Corry Wardhani, Farid Hamid. 2010. Teori Komunikasi Massa. Bogor: Ghalia Indonesia.

Panuju, Redi. 2018. Pengantar Ilmu Komunikasi. Jakarta: Prenadamedia Group.

Rofiq, Ainur. 2020. Urgensi Dakwah Pemberdayaan Masyarakat di Era Industry 4.0. Jurnal IJIC Pascasarjana IAIN Jember, Vol. 3, No. 1, Juni 2020. Diakses melalui http://jurnalpasca.iainjember.ac.id/ejournal/index.php/IJIC/article/view/620/104

Santoso, Didik Hariyadi, dkk. 2020. Media, Komunikasi dan Informasi di Masa Pandemi Covid-19. Yogyakarta: MBridge Press.

Shofiyyah, Nilna Azizatus, Haidir Ali, dan Nurhayati Sastraatmadja. 2019. Model Pondok Pesantren di Era Milenial. STAIN Curup: Belajea, Jurnal Pendidikan Islam, Vol. 4, No. 1, 2019; 1-18

Soebahar, Halim. 2019. Tantangan Baru Pasca UU Pesantren. Jember: Radar Jember Online, $25 \quad$ November 2019. Diakses melalui https://radarjember.jawapos.com/perspektif-halim/25/11/2019/tantanganbaru-pasca-uu-pesantren

Suharto, Babun. 2011. Dari Pesantren untuk Umat. Surabaya: Imtiyaz

Wazis, Kun. 2016. Komunikasi Tiga Dimensi. Jember: Jurnal Al Adalah LP2M IAIN Jember, Vol. 19, No. 1, Mei 2016)

Wazis, Kun. 2017. Komunikasi Transbudaya Pondok Pesantren: Kajian Teoritis dalam Paradigma Konstruktivis. Jurnal Lugas STIAMI Jakarta, Volume 1, Nomor 01, 2017, diakses https://ojs.stiami.ac.id/index.php/lugas/article/view/106/94

Wazis, Kun. 2019. Memaknai Komunikasi Pesantren. Koran Jawa Pos Radar Jember Edisi Jumat 24 Mei 2019, dan dipublikasikan dalam website https://radarjember.jawapos.com/2019/05/23/memaknai-komunikasipesantren/

Kun Wazis. 2020. Konstruksi Realitas Semu Mengenai Isu Terorisme-Radikalisme terhadap Pondok Pesantren. Jurnal Kajian Komunikasi Fikom Unpad Bandung, Vol. 8, No. 1 Juni 2020), diakses melalui http://jurnal.unpad.ac.id/jkk/article/view/25461/13420 